\title{
A NEW SPECIES OF TYPHLODROMUS (ANTHOSEIUS) DE LEON (ACARI: MESOSTIGMATA: PHYTOSEIIDAE) FROM SAKHALIN ISLAND, RUSSIA
}

\author{
Vladimir A. Khaustov ${ }^{1 *}$, Ismail Döker ${ }^{1,2}$ and Omid Joharchi ${ }^{1}$ \\ ${ }^{1} \mathrm{X}-\mathrm{BIO}$ Institute, Tyumen State University, Tyumen, Russia \\ ${ }^{2}$ Acarology Laboratory, Department of Plant Protection, Agricultural Faculty, Cukurova \\ University, Adana, Turkey \\ *corresponding author; e-mail: v.a.khaustov@utmn.ru
}

\begin{abstract}
Typhlodromus (Anthoseius) levis sp.n. (Acari: Phytoseiidae) is described and illustrated based on adult specimens collected from soil on the shore of Lake Tunaycha, Sakhalin Island, Russia.
\end{abstract}

KEY WORDS: Predatory mites, fauna, Typhlodromini, Sakhalin, taxonomy.

DOI: 10.21684/0132-8077-2021-29-2-257-265

\section{INTRODUCTION}

Members of family Phytoseiidae (Acari: Mesostigmata) are commonly used in Integrated Pest Management programs as biological agents of phytophagous arthropods, such as spider mites, thrips, whiteflies, and free living nematodes (McMurtry et al., 2013).

The subgenus Typhlodromus (Anthoseius) De Leon (1959), belonging to the subfamily Typhlodrominae, is one of the largest groups of predators in the family Phytoseiidae, with about 390 described species, including synonyms (Kolodochka, 2006; Chant and McMurtry, 2007; Demite et al., 2021, Döker et al., 2021). The species in this subgenus can be distinguished from Typhlodromus (Typhlodromus) Scheuten, a closely related subgenus, by the presence of dorsal seta S5 (Chant and McMurtry, 1994).

To date, four phytoseiid species have been recorded from Sakhalin Island, Russia, and this includes only one species from the subgenus Typhlodromus (Anthoseius), namely Typhlodromus (Anthoseius) povtari (Kolodochka, 1988). In this paper, we provide a complete description of a new species, Typhlodromus (Anthoseius) levis Khaustov and Döker sp.n., based on female and male specimens, collected from soil on Sakhalin Island, Russia.

\section{MATERIALS AND METHODS}

Soil samples were collected during a zoological expedition to Sakhalin Island, Russia, in August 2021. The mites were extracted using Berlese-Tullgren funnels and further preserved in vials with $96 \%$ ethanol. The specimens were cleared in lactophenol and mounted in Hoyer's medium for detailed morphological study. The taxonomic system follows that of Chant and McMurtry (2007).
The setal nomenclature for the dorsal idiosoma follows that of Lindquist and Evans (1965), as adapted by Rowell et al. (1978) and Chand and Yoshida-Shaul (1992). The setal nomenclature for the ventral idiosoma follows that of Chant and Yoshida-Shaul (1991). The chaetotaxy of legs and palps follows that of Evans (1963a, b). Adenotaxy and poroidotaxy nomenclature follows that of Athias-Henriot (1975) for the dorsal idiosoma, and Johnston and Moraza (1991) for the ventral idiosoma. The terminology of the morphological structures of spermatodactyl follows that of Beard (2001). Measurements are presented in micrometers $(\mu \mathrm{m})$ as a mean, followed by a range in parentheses. Morphological observations, illustrations and measurements were prepared using the Axio Imager A2 compound microscope (Carl Zeiss, Germany), equipped with the differential interference contrast (DIC) and the phase contrast optical systems. Figures were prepared with Adobe Photoshop CS2 software using a graphic tablet Wacom Cintiq 16. Photomicrographs were taken with an AxioCam 506 camera (Carl Zeiss, Germany). Type materials are deposited at the mite collection of the Tyumen State University Museum of Zoology, Tyumen, Russia (TSUMZ).

\section{SYSTEMATICS}

Family Phytoseiidae Berlese, 1916 Genus Typhlodromus Scheuten, 1857 Subgenus Anthoseius De Leon, 1959

\section{Typhlodromus (Anthoseius) levis Khaustov and Döker sp.n.}

Figs. 1-6 


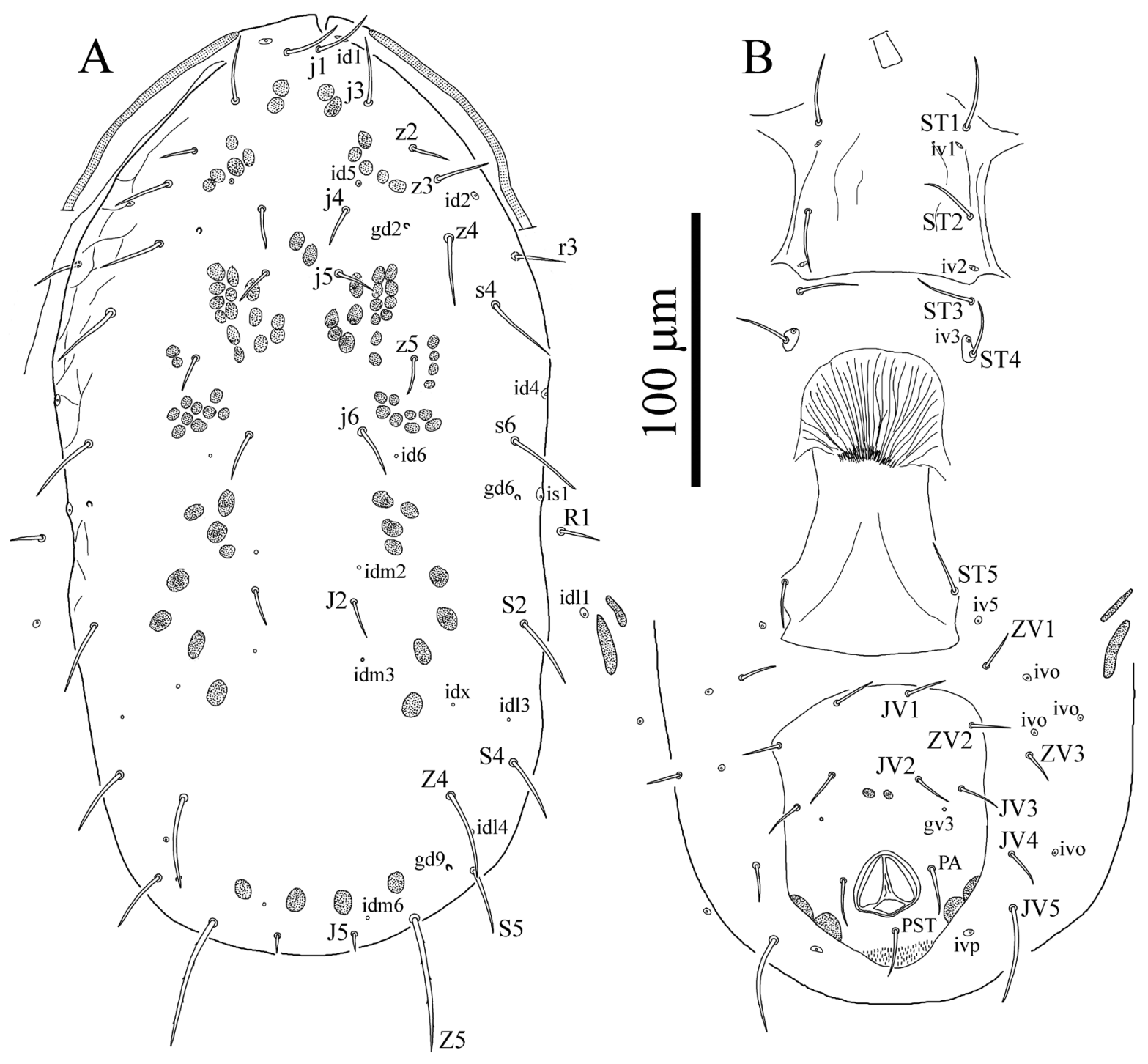

Fig. 1. Typhlodromus (Anthoseius) levis sp.n., holotype female. A-dorsal idiosoma; 2-ventral idiosoma.

Diagnosis (adult female and male). Dorsal shield oval and elongated, smooth, with some anterolateral reticulations, with three pairs of solenostomes $(g d 2, g d 6$, and $g d 9)$. Dorsal setae smooth and setiform except $Z 5$, slightly serrated in female, seta $z 4$ slightly displaced medially. Peritreme extending to level between $j 1$ and $j 3$. Sternal shield smooth, with two pairs of setae, third seta ST3 inserted on soft cuticle. Genital shield smooth. Ventrianal shield smooth, bearing four pairs of preanal setae and one pair of small rounded pores ( $g v 3)$. Calyx of spermatheca tubular, with almost parallel walls, flaring distally; atrium nodular, incorporated to calyx. Fixed digit of chelicera with five teeth and pilus dentilis; movable digit with three teeth. Genu II with seven setae. Three macrosetae present on leg IV. Ventrianal shield of male with five pairs of preanal setae. Male spermatophoral process L-shaped.
Description: Female (n=12) (Figs. 1-5).

Dorsum (Figs. 1A, 5A). Dorsal setal pattern 12A:8A (setae $r 3$ and $R 1$ off shield). Dorsal shield oval and elongated, smooth, with some anterolateral reticulation, with slight waist at level of setae $R 1$. Dorsal shield with three pairs of solenostomes ( $g d 2, g d 6$, and $g d 9$ ) and 13 pairs of visible poroids (idll off shield). Muscle-marks (sigillae) visible mostly on podosoma, length of dorsal shield 340 (326-372), width (at level of $s 4$ ) 178 (172-190), width (at level of $S 2) 173$ (165-186). All dorsal setae smooth, except $Z 5$ slightly serrated, seta $z 4$ slightly displaced medially. Measurements of dorsal setae as follows: $j 123$ (20-25), j3 24 (22-25), j4 15 (14-16), j5 15 (14-16), j6 18 (17-20), J2 16 (14-17), J5 6 (6-7), z2 13 (12-14), z3 21 (18-22), z4 25 (23-26), z5 15 (13-16), Z4 33 (31-36), Z5 52 (48-55), s4 27 (26-29), s6 30 (28-32), S2 27 


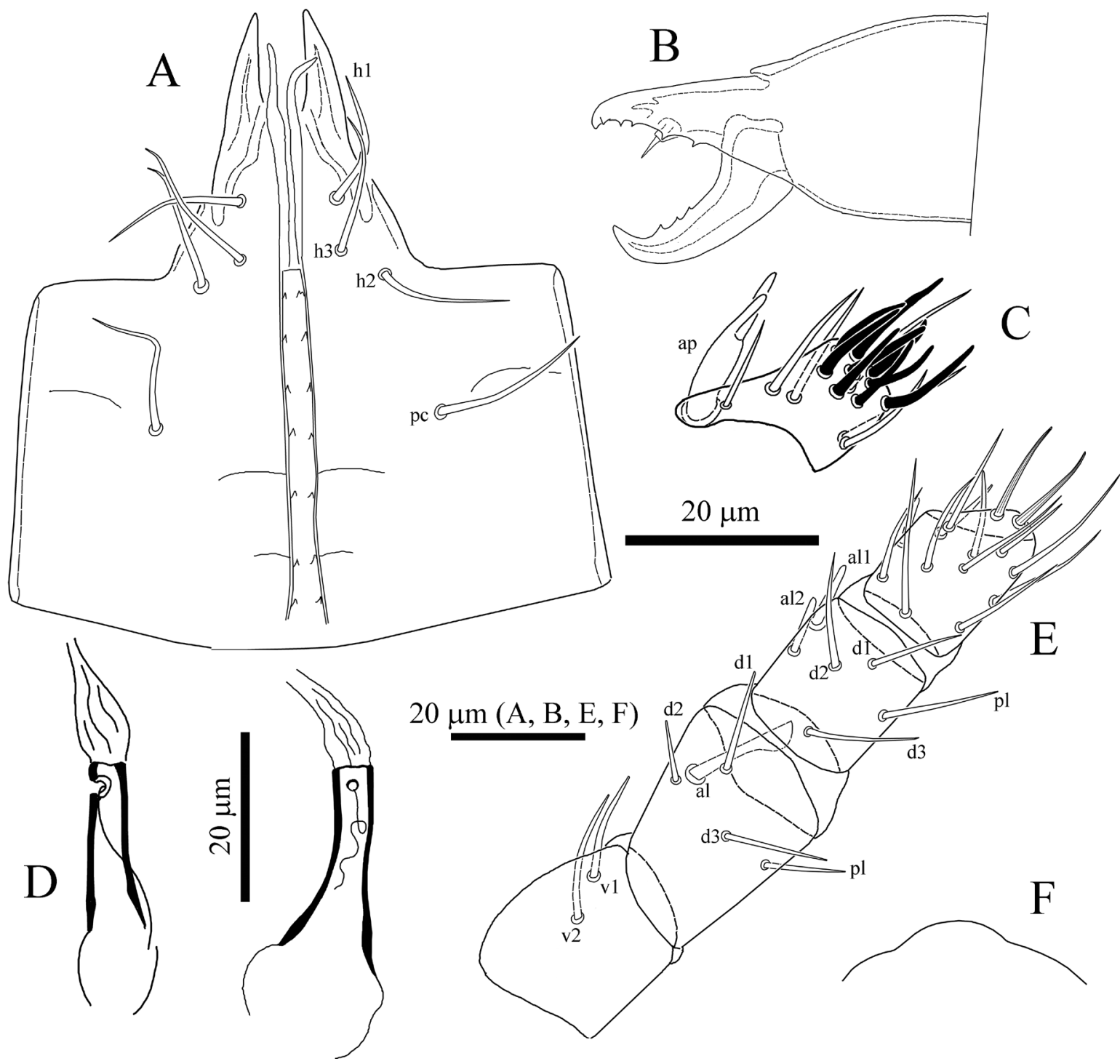

Fig. 2. Typhlodromus (Anthoseius) levis sp.n., female. A-subcapitulum; B-chelicera; $\mathrm{C}$ - dorsal view of right palptarsus; D - spermathecae; E - dorsal view of right palp (trochanter-tibia); $\mathrm{F}$-anterior margin of epistome.

(26-31), S4 26 (23-29), S5 25 (23-27), r3 19 (18-21) and $R 114$ (12-16).

Peritreme. Extending to level between $j 1$ and $j 3$, much closer to $j 1$.

Venter (Figs. 1B, 5B, 5E). Ventral setal pattern 15:JV:ZV. Sternal shield slightly striated in holotype, smooth in paratypes, lightly sclerotized, with two pairs of setae (ST1 and ST2), and two pairs of poroids ( $i v 1$ and $i v 2$ ); length (distance between base of seta $S T 1$ and poroid $i v 2) 51$ (48-53) width (distance between bases of setae ST2) 61 (58-63); setae ST3 situated on soft cuticle; setae ST4 and pair of poroids $i v 3$ on small, poor sclerotized metasternal shields. Genital shield smooth, width (at level of setae ST5) 59 (54-64), pair of paragenital poroids $i v 5$ situated on soft cuticle. Ventri- anal shield pentagonal with anterior margin convex, in some specimens with waist at level of setae $J V 3$, with four pairs of pre-anal setae ( $J V 1, J V 2, J V 3$ and $Z V 2)$, pair of para-anal seta $(P A)$ and post-anal seta $(P S T)$, and a pair of small rounded pre-anal pores $(g \vee 3)$ posteromesad $J V 3$, distance between pores 41 (37-45). Length of ventrianal shield 102 (94113), width at level of setae $Z V 275$ (69-81). Setae $Z V 1, Z V 3, J V 4, J V 5$ and five pairs of poroids on soft cuticle surrounding ventrianal shield. Setae JV5 smooth, 35 (33-38) long.

Gnathosoma (Figs. 2A-C, 2E-F, 5C). Anterior margin of epistome rounded and smooth. Hypostomal groove with seven transverse rows of denticles, each row with 2-3 teeth; subcapitular setae $h 1, h 2$, $h 3$ subequal in length 18 (17-19), slightly shorter 


\section{V.A. Khaustov et al.}

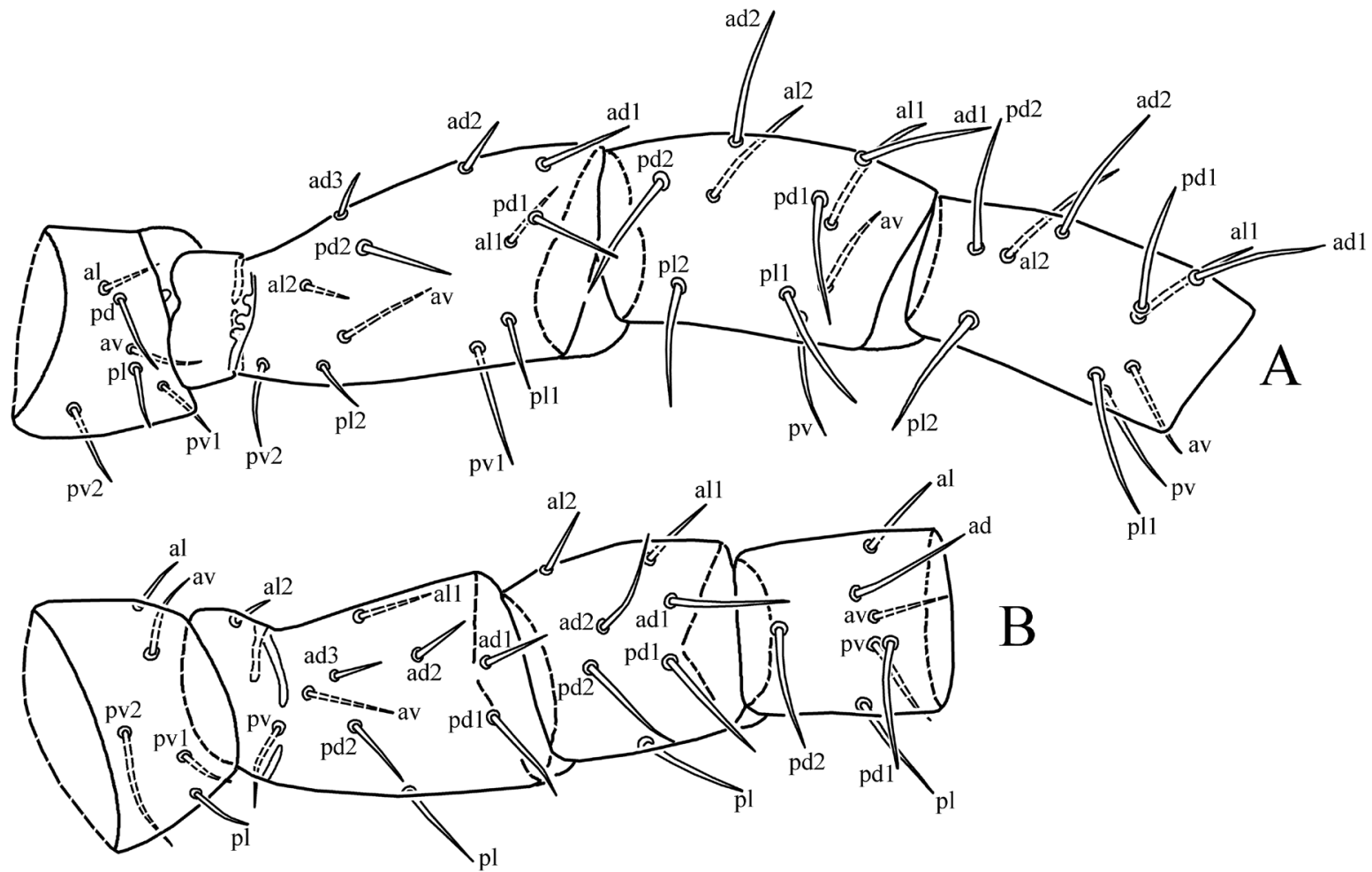

\section{$50 \mu \mathrm{m}$}

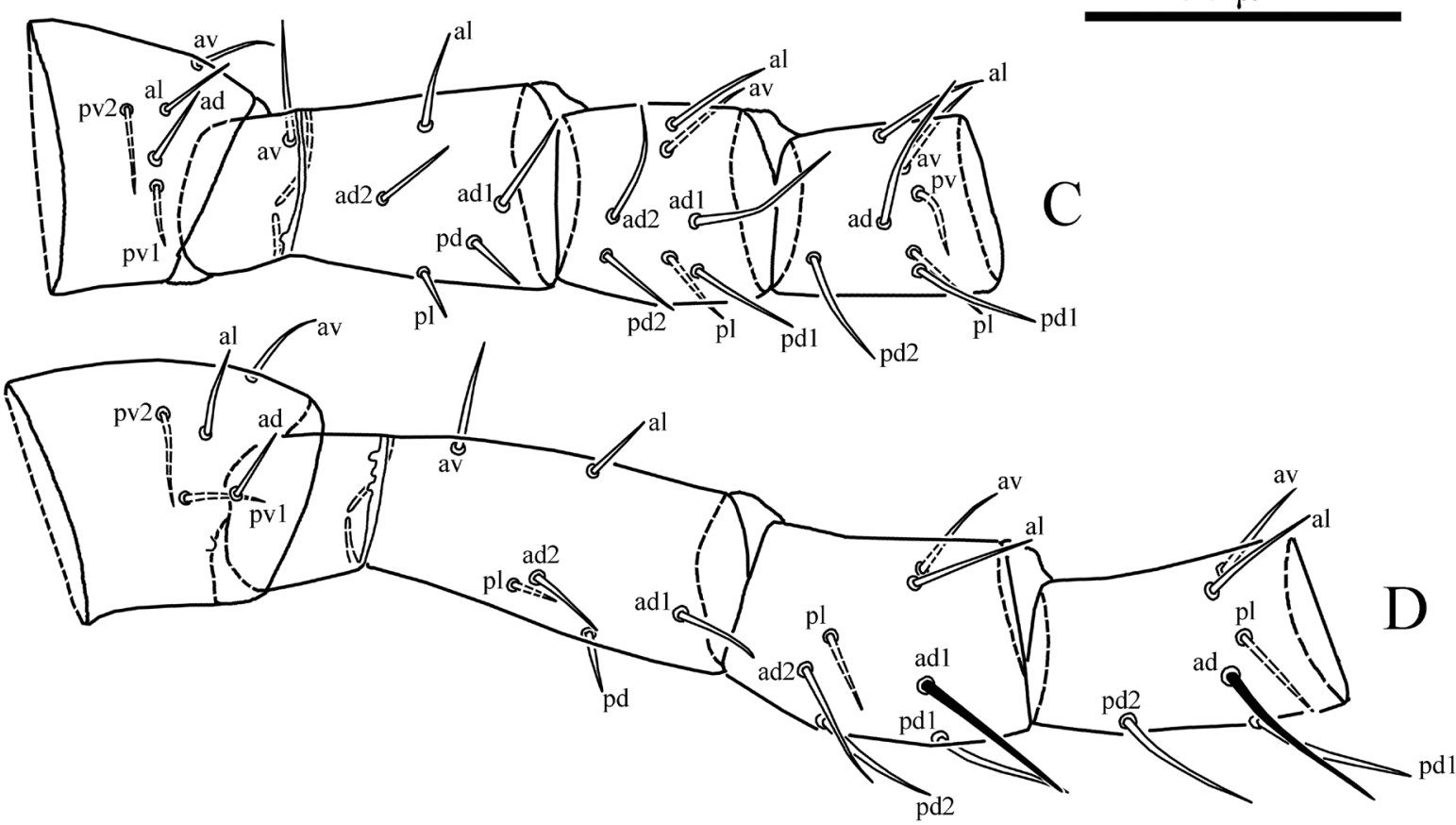

Fig. 3. Typhlodromus (Anthoseius) levis sp.n., female, right legs (trochanter-tibia). A-leg I; B-leg II; C-leg III; D- $-\operatorname{leg}$ IV.

than palp coxal setae $(p c) 21(20-21)$. Chaetotaxy of palps: trochanter with two setae; femur with five setae; genu with six setae; tibia with 14 setae; tarsus with 15 setae and two-tined apotele. Length of palp 114 (110-117). Fixed digit of chelicera 27 (26-29) long with five teeth and pilus dentilis, movable digit 30 (28-31) long with three teeth.
Spermatheca (Figs. 2D, 5D). Calyx tubular, with almost parallel walls at basal and middle parts, flaring distally; atrium nodular, incorporated to base of calyx. Major duct broad at the junction to calyx, minor duct long and visible. Calyx length 19 (18-21).

Legs (Figs. 3, 4). Lengths of legs (base of coxae to base of pretarsus): leg I 352 (343-373); 


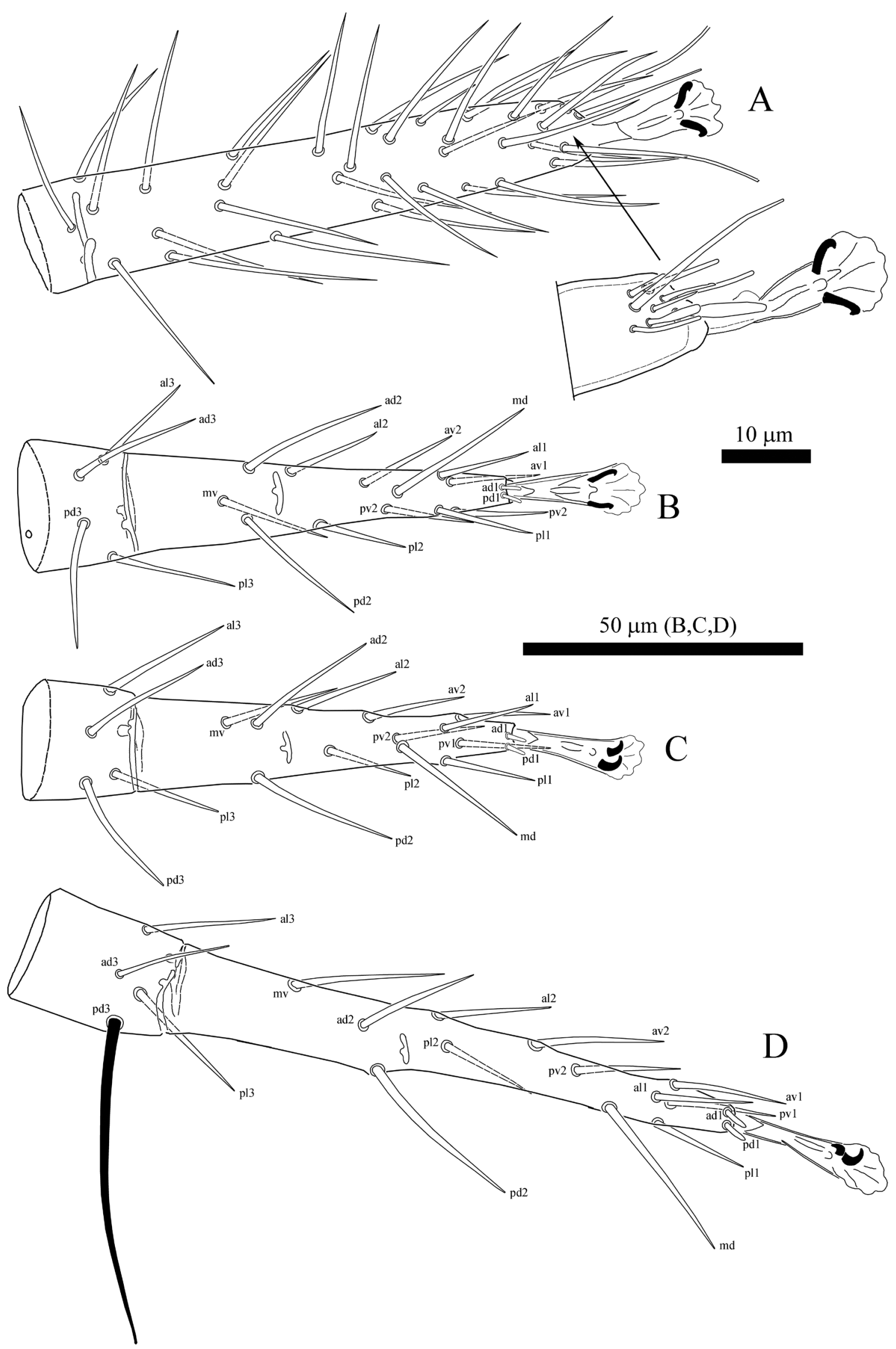

Fig. 4. Typhlodromus (Anthoseius) levis sp.n., female, right tarsi (dorsal view). A-tarsus I, apical sensorial setal cluster area enlarged; B — tarsus II; C — tarsus III; D—tarsus IV. 


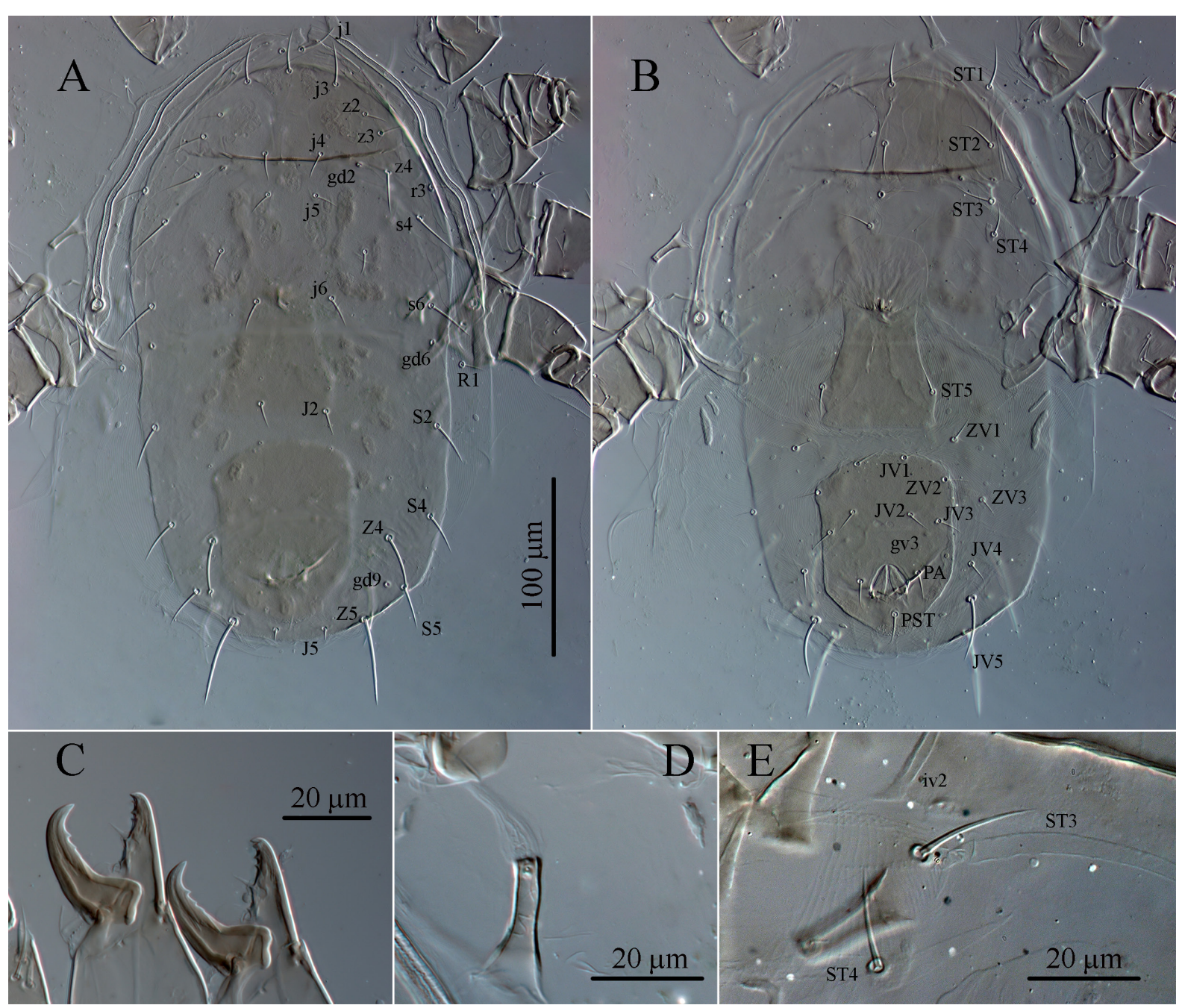

Fig. 5. DIC micrographs of Typhlodromus (Anthoseius) levis sp.n., female. A—dorsal idiosoma; B-ventral idiosoma; $\mathrm{C}$ - chelicerae; D—spermatheca; E-posterior margin of sternal shield.

leg II 270 (262-284); leg III 276 (267-297); leg IV 377 (364-394). Chaetotaxy formulae of the segments as follows: Leg I: coxa 0 0/1 0/1 0 , trochanter $10 / 11 / 21$, femur $23 / 12 / 2$, genu $2 / 1$ 2/1 2, tibia 2 2/1 2/1 2. Leg II: coxa 0 0/1 $0 / 10$, trochanter $10 / 10 / 21$, femur $23 / 12 / 11$, genu 2 2/0 2/0 1, tibia 1 1/1 2/1 1. Leg III: coxa 0 0/1 0/1 0 , trochanter $11 / 10 / 20$, femur $12 / 11 / 01$, tibia 1 $1 / 1$ 2/1 1 . Leg IV: coxa 0 0/1 $0 / 0$, trochanter 1 1/1 0/2 0, femur 1 2/1 1/0 1, genu 1 2/1 2/0 1, tibia 1 1/0 2/1 1 . Apical sensorial setal cluster of tarsus I with eight short modified setae and one elongated simple seta. Leg IV with three pointed macrosetae, Sge IV 29 (28-31), Sti IV 31 (29-33), St IV 62 (58-66). Other legs without macrosetae.

Male ( $\mathrm{n}=1$ ) (Fig. 6).

Dorsum (Fig. 6A). Dorsal setal pattern 12A:8A (setae $r 3$ and $R 1$ on shield). Dorsal shield oval, smooth, with some anterolateral and lateral reticulation, length of dorsal shield 264, width (at level of $s 4$ ) 163, width (at level of $S 2$ ) 161. Dorsal shield with three pairs of solenostomes ( $g d 2, g d 6$ and $g d 9$ ) and nine visible pairs of poroids. Muscle-marks (sigillae) visible mostly on podosoma. All dorsal setae smooth, seta $z 4$ slightly displaced medially as in adult female. Measurements of dorsal setae as follows: $j 118, j 319, j 413, j 512, j 614, J 211$, J5 6, z2 11, z3 17, z4 15, z5 12, Z4 28, Z5 39, s4 21, s6 23, S2 20, S4 20, S5 17, r3 16 and R1 11.

Peritreme. Extending to level between $j 1$ and $j 3$.

Venter (Fig. 6B). Ventral setal pattern 13:JV$4: Z V-3$. Sternogenital shield smooth with a few lateral striae, with five pairs of setae (ST1-ST5) and three pairs of poroids (iv1, iv2, iv3); length (distance between bases of setae ST1-ST5) 107, width (distance between bases of setae ST2) 53. Ventrianal shield triangular, smooth, except few striae on anterolateral corners; with five pairs of pre-anal setae $(J V 1, J V 2, J V 3, Z V 1$ and $Z V 2)$, a pair of para-anal seta $(P A)$ and post-anal seta $(P S T)$, and a pair of 


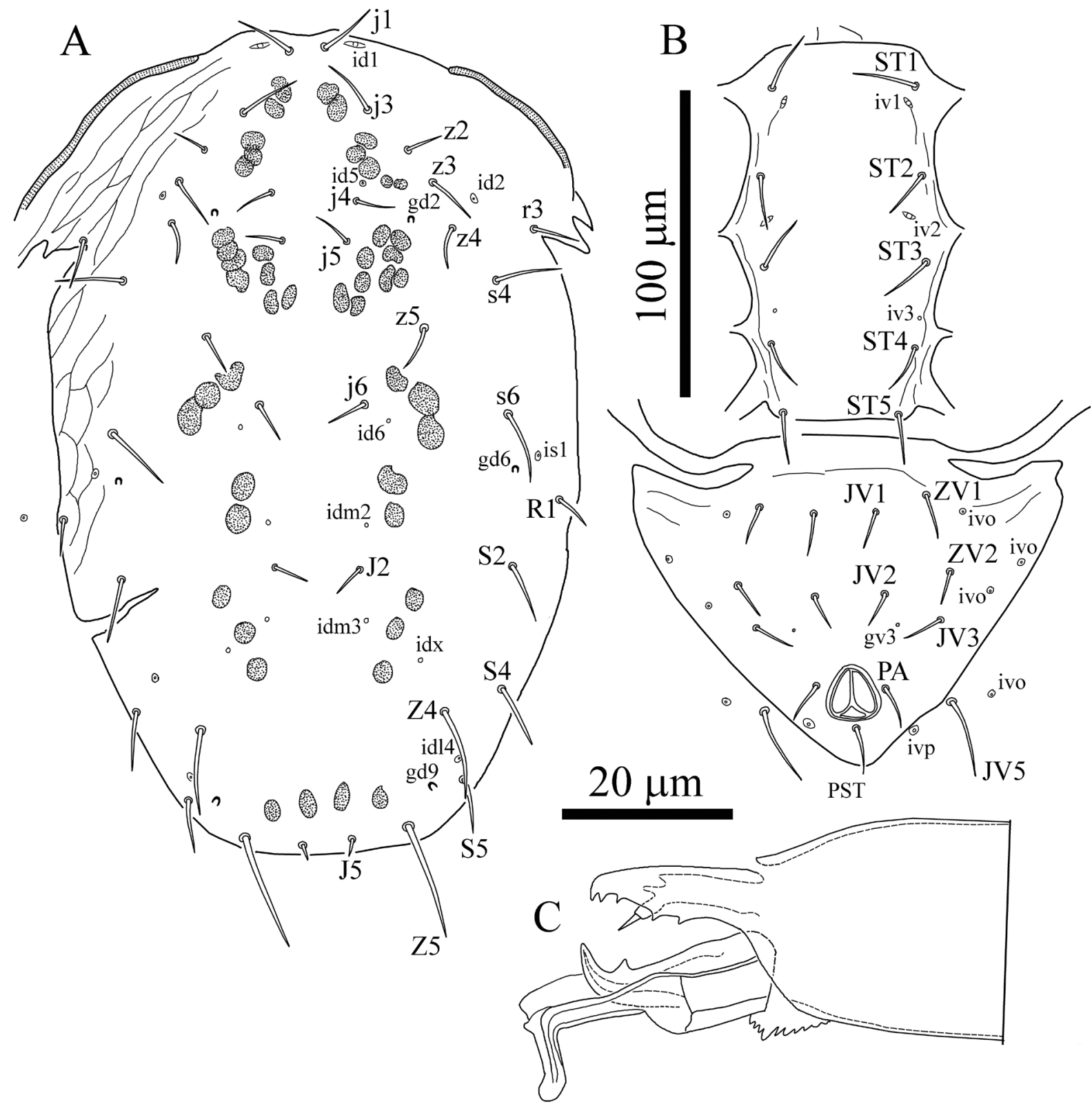

Fig. 6. Typhlodromus (Anthoseius) levis sp.n., male. A—dorsal idiosoma; B—ventral idiosoma; $\mathrm{C}$-chelicera.

small rounded pre-anal pores $(g \vee 3)$ posteromesad $J V 3$, distance between pores 35 . Length of ventrianal shield (from anterior to posterior margins) 106, width at level of anterolateral corners 138 . Seta JV5 and two pairs of poroids (ivo, ivp) on soft cuticle surrounding ventrianal shield. Setae JV5 smooth, much longer than other ventral setae, 24 long.

Gnathosoma (Fig. 6C). Chaetotaxy of palps as in adult female. Fixed digit of chelicera 21 long, with four teeth and setiform pilus dentilis; movable digit 22 long with one tooth. Spermatodactyl foot L-shaped.

Legs. Length of legs (base of coxae to base of pretarsus): leg I 303; leg II 227; leg III 228; leg IV
309. Chaetotaxy formulae of the segments as in adult female. Leg IV with three pointed macrosetae, Sge IV 24, Sti IV 25, St IV 51.

Type materials. Holotype female, 11 female and one male paratypes, Korsakovsky District, Sakhalin Oblast, Russia, $46^{\circ} 51^{\prime} \mathrm{N}, 143^{\circ} 07^{\prime} \mathrm{E}, 10$ August 2021, from soil on the shore of Lake Tunaycha, coll. A. A. Khaustov.

Etymology. The name of the species is derived from the Latin word "levis", which means smooth and refers to the species' smooth dorsal shield.

Differential diagnosis. Due to following unique combination of morphological characters - smooth dorsal shield (except some anterolateral striations), 
three pairs of dorsal solenostomes ( $g d 2, g d 6$, and $g d 9)$, two pairs of setae on sternal shield, four pairs of preanal setae on ventrianal shield, presence of small rounded pre-anal pores, three macrosetae on leg IV-Typhlodromus (Anthoseius) levis sp.n. is easily distinguished from most species of the subgenus Anthoseius. Nevertheless, Typhlodromus (Anthoseius) levis sp.n. is closely related to T. (A.) votivus (Meshkov, 1990) based on the shape of the calyx of spermatheca. However, the new species has three distinct macrosetae on leg IV, a movable digit of chelicera with three teeth, smooth dorsal and ventrianal shields and setae ST3 inserted on soft cuticle. T. (A.) votivus, on the other hand, has only one short macrosetae on leg IV, two teeth on the movable digit of chelicera, well sclerotized, with reticulated area on opisthosoma, and reticulated ventrianal shield, setae ST3 inserted on sternal shield. Additionally, the new species is also closely related to $T$. (A.) cuii $\mathrm{Wu}$ and $\mathrm{Ou}, 1998$ and T. (A.) zhongdianensis $\mathrm{Wu}$ and $\mathrm{Ou}$, in Wu et al. 2009, based on the smooth dorsal shield and on the similar lengths of dorsal setae. However, Typhlodromus (Anthoseius) levis sp.n. is distinctly different from the above-mentioned species based on the shape of the calyx of spermatheca: tubular in the new species as opposed to saccular in $T$. (A.) cuii and bell-shaped in T. (A.) zhongdianensis.

\section{ACKNOWLEDGEMENTS}

This study was supported by the grant from the Russian Science Foundation, project No. 20-6447015. We are grateful to Dr. Alexander A. Khaustov (X-BIO Institute, Tyumen State University) for collecting the material and for his valuable advice during the preparation of the manuscript.

\section{REFERENCES}

Athias-Henriot, C. 1975. Nouvelles notes sur les Amblyseiini. II. Le relevé organotaxique de la face dorsale adulte (Gamasides, protoadéniques, Phytoseiidae). Acarologia, 17: 20-29.

Beard, J.J. 2001. A review of Australian Neoseiulus Hughes and Typhlodromips De Leon (Acari: Phytoseiidae: Amblyseiinae). Invertebrate Taxonomy, 15: 73-158. DOI: 10.1071/IT99017

Chant, D.A. and McMurtry, J.A. 1994. A review of the subfamilies Phytoseiinae and Typhlodrominae (Acari: Phytoseiidae). International Journal of Acarology, 20:223-310.DOI: 10.1080/01647959408684022

Chant, D.A. and McMurtry, J.A. 2007. Illustrated Keys and Diagnoses for the Genera and Subgenera of the Phytoseiidae of the World (Acari: Mesostigmata). Indira Publishing House, West Bloomfield, 219 pp.
Chant, D.A. and Yoshida-Shaul, E. 1991. Adult ventral setal patterns in the family Phytoseiidae (Acari: Gamasina). International Journal of Acarology, 17: 187-199. DOI: 10.1080/01647959108683906

Chant, D.A. and Yoshida-Shaul, E. 1992. Adult idiosomal setal patterns in the family Phytoseiidae (Acari: Gamasina). International Journal of Acarology, 18: 177-193.DOI: 10.1080/01647959208683949

Demite, P.R., Moraes, G.J. de, McMurtry, J.A., Denmark, H. A. and Castilho, R.C. 2021. Phytoseiidae Database. Date of access: 10 Nov. 2021. http:// www.lea.esalq.usp.br/phytoseiidae/

Döker I., Khaustov V.A., Joharchi O. 2021. A new species of Typhlodromus (Anthoseius) De Leon and redescription of $T$. (A.) montanus Chant and Yoshida-Shaul from Russia. Zootaxa, 4951: 372-380. DOI: 10.11646/zootaxa.4951.2.10

Evans, G.O. 1963a. Observations on the chaetotaxy of the legs in the free-living Gamasina (Acari: Mesostigmata). Bulletin of the British Museum (Natural History) Zoology, 10: 275-303. DOI: 10.5962/bhl. part.20528

Evans, G.O. 1963b. Some observations on the chaetotaxy of the pedipalps in the Mesostigmata (Acari). Annals and Magazine of Natural History, 13: 513-527. DOI: 10.1080/00222936308651393

Johnston, D.E., Moraza M.L. 1991. The idiosomal adenotaxy and poroidotaxy of Zerconidae (Mesostigmata: Zerconina). In: F. Dusbábek and V. Bukva (Eds.). Modern Acarology. Vol. 2. Academia and the Hague, SPB Academic Publishing bv., Prague, pp. 349-356.

Kolodochka, L.A. 1988. Anew genus and a new species of the mite family Phytoseiidae (Parasitiformes). Vestnik Zoologii, 4: 42-45 [in Russian].

Kolodochka, L.A. 2006. Phytoseiid mites of the Palaearctic Region (Parasitiformes, Phytoseiidae): faunistic, taxonomy, ecomorphology, evolution. Vestnik Zoologii, Supplement 21: 1-250. [In Russian]

Lindquist, E.E. and Evans, G.O. 1965. Taxonomic concepts in the Ascidae, with a modified setal nomenclature for the idiosoma of the Gamasina Acarina: Mesostigmata. The Memoirs of the Entomological Society of Canada, 47: 1-64. DOI: 10.4039/entm9747fv

McMurtry, J.A., Moraes, G. J. de and Sourassou, N.F. 2013. Revision of the lifestyles of phytoseiid mites (Acari: Phytoseiidae) and implications for biological control strategies. Systematic and Applied Acarology, 18: 297-320. DOI: 10.11158/saa.18.4.1

Meshkov, Yu.I. 1990. A new species and unknown males of the mite genus Anthoseius (Parasitiformes, Phytoseiidae) of the USSR fauna. Vestnik Zoologii, 24: 70-74. [In Russian] 
Rowell, H.L., Chant, D.A. and Hansell, R.I.C. 1978. The determination of setal homologies and setal patterns on the dorsal shield in the family Phytoseiidae (Acarina: Mesostigmata). The Canadian Entomologist, 110: 859-876. DOI: 10.4039/Ent110859-8

Wu, W.N. and Ou, J.F. 1998. Anew species of the rhenanus species group of genus Typhlodromus in China
(Acari: Phytoseiidae). Systematic and Applied Acarology, 3: 133-136. DOI: 10.11158/saa.3.1.21

Wu, W.N., Ou, J.F. and Huang, J.L. 2009. Fauna Sinica, Invertebrata. Vol. 47. Arachnida Acari: Phytoseiidae. Science Press, Beijing, China. 511 pp. [In Chinese with English abstract]. 